\title{
The oldest and first nearly complete skeleton of a chelid, of the Hydromedusa sub-group (Chelidae, Pleurodira), from the Upper Cretaceous of Patagonia
}

\author{
Marcelo de la FUENTE ${ }^{1}$, France de LAPPARENT de BROIN ${ }^{2}$ and TERESA MANERA de BIANCO 3
}

\begin{abstract}
Key words. - Chelonii, Chelidae, Upper Cretaceous, Patagonia, Systematics.
Abstract. - A new pleurodiran (side necked) turtle is described on material from the Upper Cretaceous of Patagonia, from sediments outcropping at Cerro Blanco, Yaminué Creek, Río Negro, Argentina. The sediments are compared to those from the Pellegrini lake area referred to the middle Member of the Allen Formation, Upper Campanian-Lower Maastrichtian. Yaminuechelys gasparinii n. g., n. sp., is a pleurodiran turtle on the pelvis sutured to the shell and a chelid on the formula of cervical vertebrae and the lateral cheek emargination, deeply extended towards (as here) or up to the posterior emargination. It is the oldest record of a nearly complete skeleton of a chelid, long necked (elongated cervical vertebrae, lowered skull), and the first sufficiently known of the Chelodina-Hydromedusa group (elongated skull, lowered neural arch and centrum of the cervicals, low zygapophyses processes, strong polygoned decoration) and of the Hydromedusa sub-group (widened inner nares by reduced palatine ossification). The carapace is $41,8 \mathrm{~cm}$ long. It is more primitive than Hydromedusa (Eocene-Extant, South America) and retains primitive characters either still present or no more present in the other chelids of the Pseudemydura, Emydura and Phrynops groups (short necked) and Chelus group (long necked), representing the anterior clades of phyletic diversification [Gaffney, 1977], or evolutive grades, of the family. Such are plesiomorphic, relative to Hydromedusa, the less pronounced lateral skull emargination, wider and longer hyoid elements, wider nucal and cervical, this not drawn back, presence of lateral mesoplastra, not shortened bridge, straight borders of the not shortened and not widened posterior plastral lobe, amphicoelous sacrals and caudal vertebrae uniting amphicoelous, concavoplaty- (i.e. anteriorly concave, posteriorly flat) and procoelous or weakly procoelous elements. As Hydromedusa, Yaminuechelys n. g. retains primitive characters such as the long serie of neurals, the very lateral attachment of the axillar and inguinal processes and the attachment of the pelvis, below pleural 8 (and 7 in the extant form) and a small part of the suprapygal, and the ischitatic sutures prolonged on the xiphiplastral points. It is distinguished by the apomorphic presence of a wide and week anterior carapacial notch. Yaminuechelys n. g., or aff. Yaminuechelys spp. are known in Patagonia by fragmentary remains in a dozen of Upper Cretaceous and two Palaeocene localities. Before them, chelids are known in the world only by undefined smaller forms from Lower Albian and Upper Albian-Cenomanian Patagonian localities. In Australia, they are known from Palaeocene-Lower Eocene (no Cretaceous data before) with already extant Australian diversified forms. Yaminuechelys n.g. demonstrates how long the diversification in chelids is realized in South Gondwana before the full break of the continents.
\end{abstract}

\section{Première découverte du plus ancien squelette de tortue chélidée, sous-groupe Hydromedusa (Pleurodira, Chelidae), dans le Crétacé supérieur de Patagonie.}

\begin{abstract}
Mots clés. - Chelonii, Chelidae, Upper Cretaceous, Patagonia, Systématique.
Résumé. - La nouvelle tortue chélidée décrite provient d'un horizon argileux d'une succession d'argiles et de grès affleurant à Cerro Blanco dans le ruisseau Yaminué, Río Negro, Patagonie, Argentine, Crétacé supérieur, correspondant au Sénonien lacustre de Wichmann [1927]. Ces sédiments sont comparables à ceux de la zone du lac Pellegrini rapportés au membre moyen de la formation Allen, Campanien supérieur-Maastrichtien inférieur [Leanza et Hugo, 1999; Manera de Bianco, 1996]. Yaminuechelys gasparinii n. g., n. sp., est le plus ancien premier squelette suffisamment préservé de pleurodire (tortues à bassin fixé par suture à la carapace) chélidé. Les Chelidae (tortues d'eau douce) sont caractérisés par deux apomorphies partagées par Yaminuechelys n.g. : la formule cervicale, avec l'atlas biconcave, trois vertèbres opisthocoeles, une biconvexe, une procoele, une biconcave et une biconvexe [Gaffney, 1977; Broin et de la Fuente, 1993], et le développement de l'échancrure jugale du crâne presque jusqu'à l'échancrure dorsale postérieure (comme dans le cas présent) ou rejoignant celle-ci. Il appartient à l'un des deux groupes actuels à long cou (à cervicales allongées et crâne aplati), le groupe Hydromedusa-Chelodina, par l'abaissement des cervicales (centrum, arc neural et processus zygapophyzaires), l'allongement du crâne et la décoration de la carapace par des polygones bien marqués, et au sous-groupe Hydromedusa, genre sudaméricain éocène-actuel, par les grandes narines internes avec réduction de l'ossification des palatins. De grande taille (carapace de $41,8 \mathrm{~cm}$ de longueur), Yaminuechelys n.g. est plus primitif qu'Hydromedusa par la préservation de caractères primitifs, soit encore présents soit désormais disparus chez les au-
\end{abstract}

\footnotetext{
${ }_{1}^{1}$ Departamento Paleontología Vertebrados, Facultad de Ciencias Naturales y Museo de La Plata, Paseo del Bosque S/N ${ }^{\circ}, 1900$ La Plata, Argentina. Conicd.

2 Laboratoire de paléontologie-UMR 8569 du CNRS, Muséum national d'histoire naturelle, 8 rue Buffon, 75005 'Paris, France.

${ }^{3}$ Departamento de Geología, Universidad Nacional del Sur, San Juan 670, 8000 Bahia Blanca, Argentina.

Manuscrit déposé le 22 juin 2000 ; accepté après révision le 20 octobre 2000.
} 
tres chélidés des groupes à cou court Pseudemydura, Emydura et Phrynops et de l'autre groupe à cou long, Chelus, représentant les clades (ou grades) de diversification phylétique précédents Hydromedusa dans la famille [Gaffney, 1977]. Ces caractères plésiomorphes, variant en importance suivant les stades évolutifs au sein des groupes, sont: la moindre échancrure latérale et dorsale du crâne, les éléments de l'hyoïde plus larges et plus longs et, sur la carapace, les nucale et cervicale primitives, larges et courtes, toutes deux largement exposées jusqu'au bord antérieur (chez Hydromedusa, autapomorphie du genre, les marginales 1 sont jointives en avant de la cervicale repoussée vers l'arrière sur une nucale allongée et rétrécie à l'avant), la présence de mésoplastrons latéraux, courts et larges, le pont non raccourci et le lobe postérieur plastral étroit, non arrondi et non raccourci, sans encoche fémoro-anale. Les vertèbres sacrées sont amphicoeles et les caudales (préservées de la première à la septième), sont plus ou moins procoeles, amphicoeles ou concavoplates, plus primitives que chez Hydromedusa chez qui elles sont toutes procoeles. Comme Hydromedusa, Yaminuechelys n.g. a gardé une série primitive de huit neurales, ici non liée à la suprapygale, des attaches des processus axillaires et inguinaux très latérales, les ilions suturés sous les pleurales 8 (ou aussi les pleurales 7 chez l'actuel) et une partie de la supra-pygale et les pubis et ischions sur les xiphiplastrons (la pointe ischiale s'étendant sur la pointe xiphiplastrale). Il se distingue d'Hydromedusa par la présence d'une faible et large encoche à l'avant de la carapace, apomorphique. Yaminuechelys n.g., et/ou des formes affines sont présents en Patagonie par des éléments isolés dans au moins douze localités du Crétacé supérieur [Alcober et al., 1995; Broin, 1987 ; Broin et de la Fuente, 1993; Gasparini et de la Fuente, 2000; Lapparent de Broin et de la Fuente, 1999] et dans le Paléocène aux environs de Punta Peligro [Staesche, 1921] et à Cerro Hansen [Bona et al, 1998]. Hydromedusa est connu à l'Eocène de Cañadon Hondo, Chubut, et dans le Plio-Pleistocène d'Argentine [Broin et de la Fuente, 1993; de la Fuente, 1992] jusqu'à l'actuel [Iverson, 1992]. Composants les plus importants de la faune de tortues d'Amérique du Sud et représentants du Gondwana du Sud, les Chelidae actuels et fossiles sont confinés à l'Amérique du Sud et à l'Australasie, séparées après l'apparition des chélidés par la dérive des continents. Les plus anciens connus proviennent de l'Albien inférieur et de l'Albien supérieur-Cénomanien, Neuquén, Patagonie, avec plusieurs petites espèces inédites. Avant de s'étendre vers le nord de l'Amérique du Sud à partir du Paléocène, les chélidés voient leur nombre augmenter au Crétacé supérieur en Patagonie avec, outre Yaminuechelys n.g., des formes de petite à grande taille, lisses à ornées, dont certains apparentés aux formes actuelles [Lapparent de Broin et al., 1997; Lapparent de Broin et de la Fuente, 1999; Lapparent de Broin et de la Fuente, en prép.].

\section{INTRODUCTION}

The side-necked chelids are the most important component of the South American chelonian fauna. The living and fossil members of this family are confined to South America and Australasia. The present disjoint distribution is the result of the old Gondwanian history of this chelonian group [Pritchard, 1985; Pritchard and Trebbau, 1984; Broin 1987; Broin, 1988; Broin and de la Fuente, 1993]. The fossil record of chelid is not so extensive in Australia, where it is restricted to Tertiary (from Palaeocene) and Quaternary localities [Gaffney, 1979; 1981; 1991; Gaffney et al., 1989; Lapparent de Broin and Molnar, 2001]. On the contrary, the South American record extends from the early Cretaceous to the present [Broin and de la Fuente, 1993; Lapparent de Broin and de la Fuente, 1999] and the oldest known chelids are Patagonian. The oldest record of chelids begins in the Upper Member of the Lohan Cura Formation (Lower Albian) [Leanza and Hugo, 1995] at Cerro Los Leones, Picun Leufú Department, Neuquén Province (with at least three small and smooth chelids). It follows in Candeleros Formation (Upper Albian-Cenomanian) at El Chocón, Confluencia Department, Neuquén (with three species of smooth and small chelids including at least one taxon also present in Cerro Los Leones) [Lapparent de Broin et al., 1997; Lapparent de Broin and de la Fuente, 1999]. The richness and diversity of this chelonian fauna increase in the Upper Cretaceous. In several Patagonian localities, large and small forms, smooth or decorated, are recognized, referred to new extinct taxa and to unnamed taxa related to extant chelids, the evolutive stage of which is [Gaffney, 1977] : short necked forms (Pseudemydura SIEBENROCK, 1901; the Emydura BONAPARTE, 1836, group, then the Phrynops WAGLER, 1830, group) and long-necked taxa (Chelus DumÉRIL, 1806, then the Hydromedusa WAGLER,
1830, and Chelodina Fitzinger, 1826, group) [Bona et al., 1998; Broin, 1987; Broin and de la Fuente, 1993; Gasparini and de la Fuente, 2000; Lapparent de Broin and de la Fuente, 2001]. Hydromedusa is known from the Lower Eocene of the Chubut Province at Cañadon Hondo [references in Broin and de la Fuente, 1993] where the fossil form is well recognized as a member of the genus, characterized by the elongated and anteriorly narrowed nuchal with the autapomorphic marginals 1 meeting forward the moved back cervical. It is also known from the Plio-Pleistocene of Argentina [de la Fuente, 1992] up to now. The two extant species of Hydromedusa are H. tectifera COPE, 1869, present in the Buenos Aires Province and surrounding northern countries, and H. maximiliani (MIKAN, 1820) in Brazil. Several Phrynops spp. are also extant in Argentina, in the Buenos Aires Province [Iverson, 1992].

Long-necked chelids remains referred to Hydromedusa sub-group and either belonging to Yaminuechelys n. g., or to aff. Yaminuechelys spp., have been found in other Upper Cretaceous Patagonian localities. In particular, these turtles are represented by isolated plates and cervical vertebrae at : El Abra and Trapal-có (Los Alamitos F.), Laguna Cari Laufquen Chica (Angostura Colorada F.), or isolated plates only at: Los Alamitos and El Palomar (Los Alamitos F.), Rio Negro Province [see Broin and de la Fuente, 1993]. Also isolated plates are found at: Abella Negra-Bajo Arriagada (Los Alamitos F.), Jagüel-Paso Córdoba [Abel data, Muñoz pers. comm.] and Cinco Saltos-Lago Pellegrini (Anacleto Formation) [Heredia and Salgado data; Heredia and Salgado, 1999; Leanza and Hugo, 1999], Rio Negro; Filo-Morado-Ñancucheo Guillermo (Neuquén group) and Sierra del Portezuelo (Portezuelo F.), Neuquén Province (Abel data, Muñoz pers. comm.); Cañadon Amarillo (Neuquén group), Mendoza Province [Pr Bianchi data] [Alcober et al., 1995]; La Colonia (La Colonia F.), Chubut 
[Gasparini and Fuente, 2000]. Isolated plates are found (Punta Peligro) [Staesche, 1921], and occasionally associated cervical vertebrae or articulated with partial shells (Cerro Hansen, Salamanca F.) [Bona et al, 1998], in the Palaeocene of the Chubut. In this article we describe the first and the oldest Cretaceous chelid specimen with an almost complete and articulated skeleton. This specimen is assigned to a new genus and species of the Hydromedusa sub-group, more primitive than the extant form. This new long-necked species adds a new chelid named component to the Cretaceous chelonian fauna of South America and particularly of Patagonia, known at the present by other four named chelid taxa [Lapparent de Broin and de la Fuente, in prép.] besides the numerous unnamed other chelid taxa, some Podocnemididae and the Meiolaniidae [Broin and de la Fuente, 1993].

\section{SYSTEMATICS}

\section{Ordo Chelonii Brongniart (LATREILLE), 1800 Infra-ordo Pleurodira COPE, 1864 Family Chelidae GRAY, 1825 Yaminuechelys $\mathrm{n}$. g. Yaminuechelys gasparinii $\mathrm{n}$. sp.}

Etymology - Yaminue (toponimic name of a Patagonian creek) and Chelys (turtle in greek). The species is dedicated to Dr Zulma Gasparini, palaeontologist of the Facultad de Ciencias y Museo de La Plata, Argentina.

Type locality and age - Cerro Blanco, Rio Negro Province, Argentina. The turtle was found in a mudstone level belonging to a succession of mudstones and sandstones named as lacustrine Senonian by Wichmann [1927] that are outcropping at Yaminué Creek, Cerro Blanco, 40 43'57' S, $67^{\circ} 10^{\prime} 12$ " W [Manera de Bianco, 1996]. These sediments are similar to those of Lago Pellegrini area which are referred [Andreis et al., 1974] to the middle Member of the Allen Formation, Upper Cretaceous in age, Upper Campanian-Lower Maastrichtian [Leanza and Hugo, 1999]. They have a similar association of finely granulated sandstones and mudstones and absence (or scarceness in Lago Pellegrini area) of psammites. They also contain similar Mesozoic continental fauna and flora.

Holotype - Museo Municipal de Ciencias Naturales "Carlos Darwin" of the city of Punta Alta, Buenos Aires Province, MPA 86-86-IC: skull, hyoid apparatus, atlas, axis, sixth, seventh and eighth cervical vertebrae, left and right scapular girdle, left and right humeri, right radius and ulna, pelvic girdle, left and right femora, right tibia and fibula, the two sacral and seven caudal vertebrae, carapace and most of the plastron (without the anterior lobe).

Diagnosis - Same diagnosis for the genus and species by monotypy. Long necked (elongated vertebrae, flattened skull) chelid turtle belonging to the HydromedusaChelodina group on the elongated skull and the strongly polygoned decoration of the carapace, and to the Hydromedusa sub-group on the large bony aperturae narium internae. Large size (carapace $41,8 \mathrm{~cm}$ long). Carapace with an apomorphic shallow and wide anterior "nuchal" emargination. More primitive than Hydromedusa on the :

- less emarginated skull from laterally towards the back dorsally: larger postorbital and jugal, more extensive exposition of the parietal, supraoccipital and squamosal in dorsal view;

- the hyoid apparatus with relatively wider and longer components : entoglossa (i.e. hypoglossa), hyoid body and horns;

- the short and wide nuchal, twice wide as long, the wide and short marginal cervical scute, three times wider than long, both widely exposed anteriorly;

- the presence of lateral mesoplastra, short and wide;

- the narrow posterior plastral lobe not rounded and not shortened such it is in Hydromedusa : it is relatively long (as long as wide at its basis), twice the axillo-inguinal distance (relatively short bridge but not as much as in Hydromedusa), without extroverted xiphiplastral points and femoro-anal notch. As in Hydromedusa, Yaminuechelys n.g. retains a primitive long neural serie, of 8 plates here and separated from the suprapygal, axillar buttresses attached only onto the lateral margin of the first pleurals at the third peripherals level and inguinal buttresses extending below the seventh peripheral and the lateral limit of the pleurals 5 . Preserved hind vertebrae more primitive than in Hydromedusa, where the sacrals and caudals are procoelous, with, from forward to back, two amphicoelous sacral vertebrae and caudals which are successively two weakly procoelous, one amphicoelous, one amphicoelous or concavoplatycoelous (i.e. anteriorly concave and posteriorly flat), two concavoplatycoelous as in some Phrynops, the other caudals of which are procoelous, and one amphicoelous.

Description - Skull (fig. 1) suboval in outline, long; interorbitary space as wide as the orbits, relatively narrower than in Phrynops and Chelus, the two clades immediately anterior to Hydromedusa and Chelodina in the established phylogeny of the Chelidae [Gaffney, 1977], but wider than in Hydromedusa and Chelodina, nearly dorsally located as in extant species of Hydromedusa and Chelodina [see figures in Gaffney, 1977]. Slight posterior temporal and deep cheek emargination as in the living species of Hydromesusa. The anterior margin of the skull is eroded, but the disposition of prefrontals and frontals show that minute nasals may have been present like those in Hydromedusa. The frontals are not interrupted by the meeting prefrontals as it occurs in part of the extant specimens of $H$. tectifera. In lateral view, the skull is dorsoventrally depressed as in extant Hydromedusa spp. On each side, the strong cheek emargination makes clearly visible in dorsal view the pleurodire pterygoid trochlea, the fossa temporalis inferior and the pterygoid, prootic, opisthotic and quadrate bones (fig. 1A) as in other extant chelids of the Phrynops group, Chelus, Chelodina and Hydromedusa. The cheek emargination is limited by the postorbital, parietal, supraoccipital and squamosal. It is more extended than that seen in Chelus, which has a much less elongated skull, but less than that of Hydromedusa and still less than in Chelodina where the posterior and the cheek emarginations are meeting. Relative to Chelodina and Hydromedusa, the parietals and the supraoccipital have a wider exposition in 

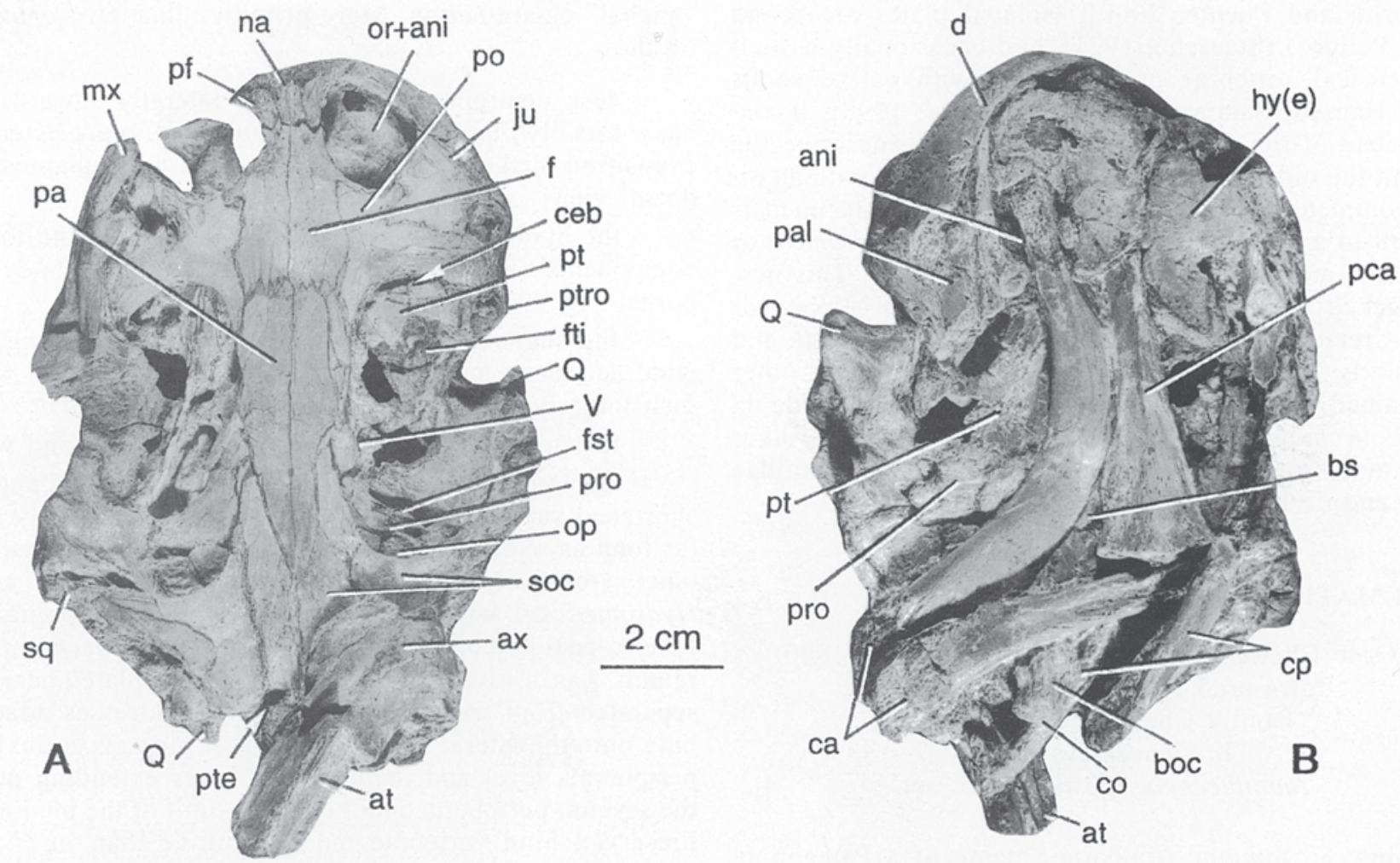

FIG. 1. - Yaminuechelys gasparinii n. g., n. sp., Upper Cretaceous, Cerro Blanco, Río Negro Province, Argentina. MPA 86-86-IC. A : skull, atlas and axis, dorsal view; B : skull and hyoid apparatus, ventral view. For understanding of the bone limits, see figures in Gaffney [1977].

FIG. 1. - Yaminuechelys gasparinii n. g., n. sp., Crétacé supérieur; Cerro Blanco, province du Rio Negro, Argentine. MPA 86-86-IC. A : crâne, atlas et axis, vue dorsale; B : crâne et hyoüde, vue ventrale. Pour la compréhension des limites des os, voir les figures de Gaffney [1977]. ani, apertura narium internae; at, atlas; ax, axis; bs, basisphenoid; boc, basioccipital; ca, anterior hyoid horns; ceb, anterior border of the ched emargination; co, occipital condyle; $\mathrm{cp}$, posterior hyoid horns; $\mathrm{d}$, dentary; $\mathrm{f}$, frontal; fst, foramen stapedio-temporale; fti, fossa temporalis inferior, hy(e), hypoglossum (" entoglossum »); ju, jugal; mx, maxillary; na, nasal place; op, opisthotic; or, orbit; pa, parietal; pal, palatine; pca, pars carinata; pf,prefrontal; po, postorbital; pro, prootic; pt, pterygoid; pte, posterior temporal emargination; ptro, processus trochlearis pterygoidei; Q, quadrate; soc, supraoccipital; sq, squamosum; V, foramen nervi trigemini.

dorsal view; the supraoccipital is a little longer but overall much wider. The posterior temporal arch is as long as in Chelus but, in the latter, it is mainly composed of the less reduced parietals instead of the large supraoccipital in Yaminuechelys. The part of the right pterygoid (partially preserved) that contributes to the processus trochlearis pterygoidei, as in all pleurodires, is exposed, partially eroded in dorsal view. This process extends posterolaterally about one third across the fossa temporalis inferior. Forward, two large bony aperturae narium internae are present as in the two extant species of Hydromedusa, larger than in other chelids, nearly only visible from above here because most of the palate, the basicranium and the occipital skull view are hidden by the hyoid apparatus (fig. 1B). The lower jaw is attached to the skull. Only the right dentary and a minute portion of the left one are preserved: they are sutured at the symphysis as in the chelids of the Phrynops group, Chelus, Chelodina and Hydromedusa [see Gaffney, 1977], slend and curved as in Hydromedusa. The triturating surface is hidden but, as in H. maximiliani, the lateral margin has not posterior unhooking, a difference from $H$. tectifera.

The preserved elements of the hyoid apparatus (fig. 1B) [see Bour and Pauler, 1987; Guibé, 1970; Romer, 1956] are: the ventral "entoglossa" of Siebenrock, or hypoglossa of Fürbringer (i.e not the entoglossum or processus lingualis), the pars carinata of the hyoid body, the horns, i.e. ceratobranchialia anteriora (cornua majora) and posteriora (cornua minora). The anterior parts of the hyoid body are hidden by the hypoglossa which are relatively larger than in Hydromedusa, with their lateral notches directed posterolaterally, as in Hydromedusa but more excavated, and shorter than in Phrynops and much shorter than in Chelus. The pars carinata is expanded distally and has an anterior strong keel that became blunt distally, this keel being differently developed in extant Hydromedusa spp., Chelus fimbriata (SCHNEIDER, 1783), and Phrynops group. The hyoid anterior horns are strongly developed in Yaminuechelys n.g. and, as in Phrynops spp. and $H$. tectifera, they are larger than the posterior. A different condition is seen in Chelus fimbriata with narrower extremities of the anterior horns.

The atlas is a complete vertebra like the axis (fig. 1A), a derived condition of the evolved long-necked chelids (synapomorphy or homoplasy). Although the axis is not completely preserved, it could be estimed that the atlas is more than half the length of the axis. Although the main sutures are vanished, a small intercentrum is recognized: the zygapophyseal facets being not preserved, it is not possible to see if an horizontal (derived condition seen in Chelodina 
and Hydromedusa) or an oblique or vertical articulation (more primitive conditions seen in the remaining chelids) was present. The axis preserved a developed anterior-dorsal process (a primitive condition lost in Hydromedusa but preserved in Chelodina). The remaining preserved cervical vertebrae are a sixth procoelous with lowered postzygapophyses process (fig. 2F-G), a seventh biconcave (fig. 2A-D) and an eighth biconvexe (fig. 2B-E). These vertebrae have narrow dorsal arch centra with different shape of the ventral keel : curved and moderately developed in the sixth, and strongly developed and straight in the seventh and eighth. In all these vertebrae the lateral apophyses are well developed, the prezygapophyses (not preserved in the seventh) are widely spaced and the postzygapophyses are joined to form a single semicircular articulating surface (sixth and seventh), slightly separated (in the eighth).

The two sacral vertebrae and the seven preserved caudal vertebrae are flattened and slightly moved from their natural position. The central articulations are successively amphicoelous (sacral vertebrae), weakly procoelous (first, second caudals), amphicoelous (third), concavoplatycoelous or amphicoelous (fourth), concavoplatycoelous (fifth, sixth) and amphicoelous (seventh last preserved caudal), contrary to the procoelous condition seen in Hydromedusa. The procoely is also not completely established in the extant Phrynops group, for example in Acanthochelys macrocephala (RHODIN, MITTERMEIER and MCMORRIS, 1984) and in Phrynops hilarii (DUMERIL and BIBRON, 1835). As observed at least in some Phrynops spp. and Hydromedusa tectifera, the transverse apophyses of the caudals posterior to the second one (caudals 3 and 4 at least) are long at their basis.

The carapace (fig. 2) is conformed (number of plates and scutes) as usual in most of chelonians. It is large (41,8 $\mathrm{cm}$ long on $33,8 \mathrm{~cm}$ wide) low, flattened and roughly oval in outline with convergent anterolateral margins and with a shallow nuchal notch instead of a rounded border on the much longer and narrower nuchal in Hydromedusa (with often a very shallow notch in $H$. tectifera). The nuchal bone width is twice its length; a nuchal much wider than long is a primitive condition of the chelonians. The shallow anterior "nuchal" emargination in Yaminuechelys n.g. is formed by the elongated medial margin of the first peripherals and the lateral part of the nuchal bone. In the present state of knowledge, it is a derived character relative to the primitive chelids, synapomorphic for Yaminuechelys and affinis form from the Palaeocene. An anterior emargination of the wide nuchal is known in other Cretaceous Patagonian forms, but differently constituted; however, the anterior border of the wide nuchal of another form from Ocho Hermanos farm is unknown (Lapparent de Broin and de la Fuente, in prep.). The anterior peripherals are not elongated such as they are in most of the other chelids and particularly in Hydromedusa, but, as in Hydromedusa, the first pleurals and the first neural are elongated relative to the primitive condition preserved in Pseudemydura and the Emydura group. The first neural bone is almost twice in length the second one and ovorectangular in shape, as in some specimens of $H$. tectifera, while it is often hexagonal short sides behind in other $H$. tectifera specimens and in $H$. maximiliani (the primitive condition); the neural series follows with six hexagonal neural bones, hexagonal short sides in front, and finishes with a small pentagonal neural bone separated from the suprapygal by the meeting of the eighth pair of pleural bones ( 6 neurals in H. tectifera and 8 neurals in $H$. maximiliani, the eighth meeting or not the suprapygal). The neural formulae are: 4-6-6-6-6-6-6-5 (number of sides) and $1>2>3>4>5=6>7>8$ (relative length of neurals). The cervical scute is three times wider than long, a primitive condition also seen in Notoemys CATTOI and FREIBERG, 1961, from the late Jurassic of Neuquén Province, Argentina, and other basal pleurodires and cryptodires, not separated from the anterior border by the meeting marginals 1 , as it is autapomorphically in the genus Hydromedusa. The vertebral serie is narrowed from the first to the fourth, as in Hydromedusa, but the vertebral 1 is not abruptly narrowed so that not to cover the postero-lateral borders of the nuchal as in the two extant species of Hydromedusa. Different from that of the extant Hydromedusa spp., the vertebral 5 covers the posterior border of the carapace. In ventral view, as in Hydromedusa, the axillar buttress is attached to the very lateral margin of the first pleural bone and the third peripheral bone, while the inguinal buttress extends below the seventh peripheral bone and the fontanelle between this plate and the lateral extremity of the pleural 5, incompletely ossified. The posterior plastral lobe is the longest plastral element. Likewise, the posterior plastral lobe is twice the axillo-inguinal distance. A partial hyoplastron, a complete mesoplastron, hypo and xiphiplaston are well preserved on left side. The short and wide left preserved mesoplastron is cuneiform in shape, included between the hyo and hypoplastron. Two plastral fontanelles can be observed in the holotype of Yaminuechelys n.g. The largest one is the central fontanelle between hyo and hypoplastra and the smaller is placed between the hypo and xiphiplastra. The posterior plastral lobe is as wide (at its basis) as long. The lateral margins of the posterior plastral lobe are convergent posteriorly, ending in a moderate $\mathrm{V}$ shaped anal notch, without extroverted xiphiplastral points as in more primitive forms such as Notoemys and some Hydromedusa specimens and without femoro-anal notch as in Hydromedusa, not rounded and shortened as in Hydromedusa. The bridge is shortened relative to more primitive chelonian forms but not as much as in Hydromedusa.

The preserved limb and girdle bones conform to the chelid anatomy. The pelvis is linked by sutures to the carapace, a character of pleurodires, the ilia below the pleurals 8 and a part of the suprapygal, the pubis and ischia on the xiphiplastra, with the posterior ischiatic extremities on the xiphiplastral extremities. The ischiatic extremities are primitively posteriorly pointed and not rounded as in Hydromedusa.

Discussion - The chelids turtles are a freshwater aquatic to semiaquatic group of pleurodires, characterized by two main autapomorphic conditions present in Yaminuechelys n.g. : the formula of articulations of the cervical vertebrae including, after the biconcave atlas, three opisthocoelous vertebrae, a biconvex, a procoelous, a biconcave and a biconvex [see Gaffney, 1977; Broin and de la Fuente, 1993] and the development of the lateral cheek emargination of the skull nearly up or up to the back of the dorsal face of the skull. A basic dichotomy in chelids turtles have been recognized [Boulenger, 1889] on the extant forms : chelid with a neck shorter than the dorsal vertebral column 

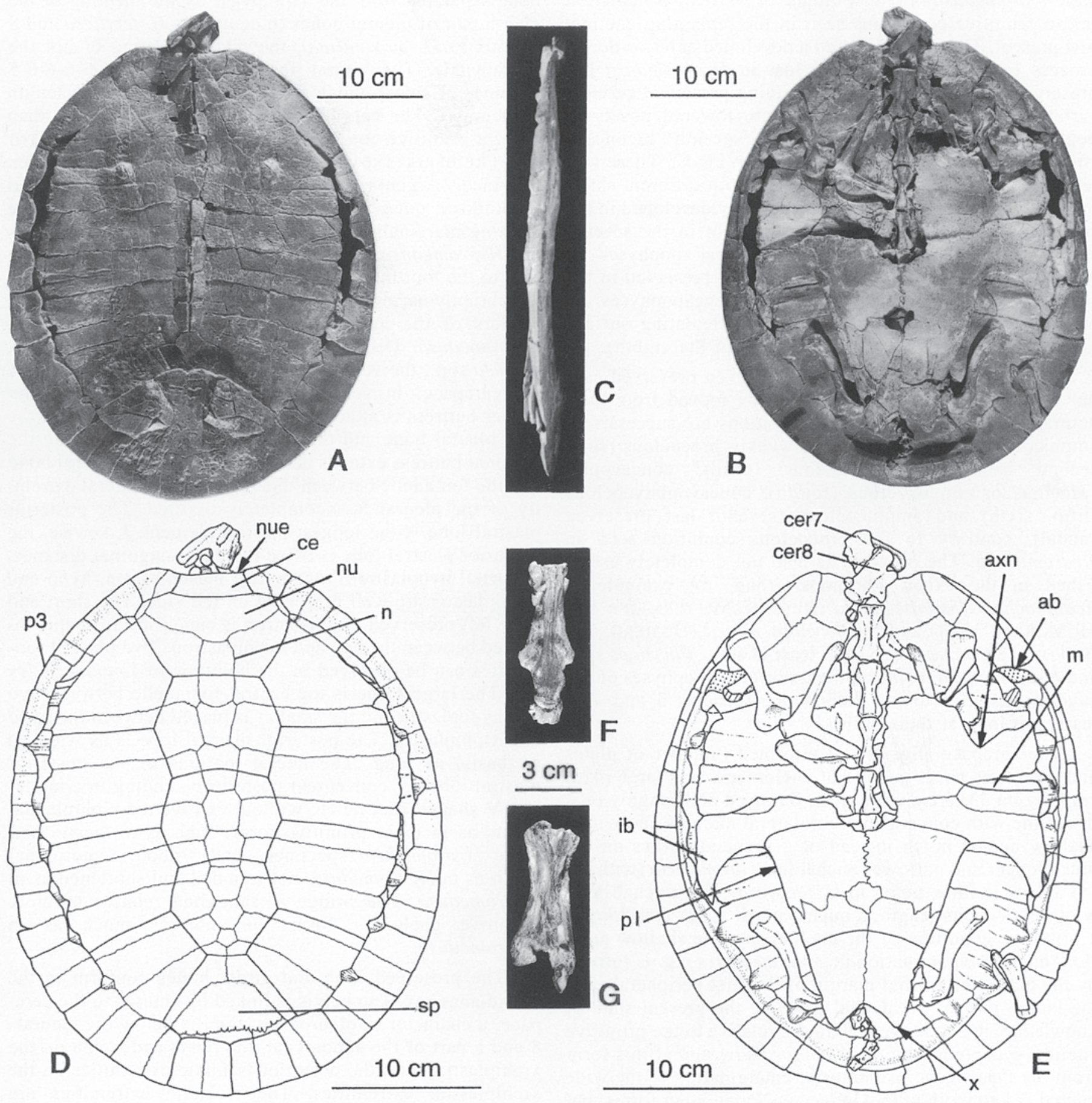

FIG. 2. - Yaminuechelys gasparinii n. g., n. sp., Upper Cretaceous, Cerro Blanco, Río Negro Province, Argentina. MPA 86-86-IC. A, D: carapace, dorsal view; B, E : carapace, plastron, axial and appendicular bones, ventral view; C : shell, left lateral view; F, G : procoelous sixth cervical vertebra, ventral and lateral views. For the understanding of the bone names, see Pritchard and Trebbau [1984].

FIG. 2. - Yaminuechelys gasparinii n. g., n. sp., Crétacé supérieur, Cerro Blanco, province du Rio Negro, Argentine. MPA 86-86-IC. A, D : carapace, vue dorsale; $\mathrm{B}, \mathrm{E}$ : carapace, plastron, squelette axial et appendiculaire, vue ventrale; $\mathrm{C}$ : carapace, vue latérale gauche; F, G : sixième vertèbre cervicale procoele, vues ventrale et latérale.

Pour la nomenclature des os, voir les figures de Pritchard et Trebbau [1984].

axn, axillary notch, anterior limit of the bridge; ab, axillar buttress; ce, cervical scute; cer7, cer8, cervical vertebrae 7, 8 ; ib, inguinal buttress; m, mesoplastron; n, neural; nu, nuchal bone; nue, nuchal emargination; p3, peripheral 3; pl, posterior lobe; sp, suprapygal; x, xiphiplastral point.

Bull. Soc. géol. Fr:, 2001, n ${ }^{\circ} 2$ 
(Pseudemydura, Emydura group and Phrynops group); chelids with a neck longer than the dorsal vertebral column, by the lengthening of each vertebra (Chelus, Chelodina and Hydromedusa). In this group of Boulenger [1889], Chelus differs from the two other genera because it has preserved the high processes of postzygapophyses of the cervical vertebrae, as in the more primitive forms while Hydromedusa and Chelodina have lowered postzygapophyses processes. On the elongated and lowered cervicals and their lowered postzygapophyses processes, Yaminuechelys n.g. is clearly a member of the long-necked group of chelids including Chelodina and Hydromedusa. The strong polygonal decoration is also shared by the three taxa, although also by Pseudemydura. The homoplastic development from a common moderately decorated ancestor is one of the possible hypothesis to explain the strong decoration in the two groups. Other characters given in the diagnosis show that the evolutive stage of Yaminuechelys n.g. is intermediate between, on the one hand, Phrynops and Chelus and, on the other hand, Hydromedusa and Chelodina (depending on characters) but it is clearly a member of a monophyletic Hydromedusa sub-group, on the autapomorphic cranial character of large aperturae narium internae with reduced ossification of palatines (medially meeting or not the vomers according to the specimens in $H$. tectifera, a trait not clearly visible in the figures owing to the hyoid presence). Relative to other fossil and extant chelids, both still share the primitive chelid character of a very few reduced neural serie, as in some of the lineages of Phrynops and of Chelodina. Yaminuechelys n.g. and/or affines forms of Yaminuechelys n.g. are present in a dozen of Upper Cretaceous Patagonian localities. Yaminuechelys n.g. is also clearly related with the unnamed large fossil form from Cerro Hansen area, Chubut, Salamanca Formation, lower
Palaeocene [Bona et al., 1998, Fig. 3A-D, specimen MPEF 527], both belonging to the long necked ChelodinaHydromedusa group, on the lowered cervicals with low postzygapophyses processes, and both more primitive than Hydromedusa on the wide and short nuchal with the apomorphic anterior notch of the carapace which characterize them. As seen above, Hydromedusa is known fossil from the Lower Eocene of the Chubut Province and the Plio-Pleistocene up to now in Argentina : the present work demonstrates that the subgroup Hydromedusa was separated long before the first record of this genus. Since Hydromedusa is, with Chelodina, the most recent clade in the phylogeny of the Chelidae, all the other groups of the family were also present during the Upper Cretaceous. This confirms the previous data [Broin and de la Fuente, 1993; Lapparent de Broin and de la Fuente, 1999; Lapparent de Broin et al., 1997] according to which the radiation of the Chelidae occurred as early as the Lower Cretaceous in South Gondwana.

Acknowledgements. - For access to material and help, we warmly thank J.L. Bianchi (Museo de Ciencias Naturales y Antropologicas "Juan Cornelio Moyano", Mendoza), J. Bonaparte (Museo Argentino de Ciencias Naturales, Buenos Aires), R. Bour (Muséum national d'histoire naturelle, Paris), J. Calvo and L. Salgado (Museo de la Universidad del Comahué, Neuquén), E. Gaffney (American Museum of Natural History, New York), R. Coria (Museo de Plaza Huincul), R.D. Carolini (Museo de El Chocón), C. Muñoz (Museo Provincial Carlos Ameghino, Cipoletti), R. Pascual (Facultad de Ciencias Naturales y Museo de La Plata), P. Vanzolini (Museu de Zoologia, Universidade de São Paulo). We warmly thank M.-Cl. Van Dyck - Groessens (Université de Louvain-la-Neuve) and L. Salgado (Museo de la Universidad del Comahue) for the correction of the manuscript, C. Deschamps (Museo de La Plata), J.-Cl. Rage and B. Battail (Laboratoire de Paléontologie, Muséum national d'histoire naturelle, Paris) (translation into English), J. Posik (Museo de La Plata) (preparation of fossil material), H. Costa (photographs), J. González and F. Pilard (figures). This research was partially supported by the PIP $0062 / 98$-CONICET.

\section{References}

Alcober O., Martinez R., Bianchi J.L., Milana J.P. \& BauzÁ (1995). Una nueva localidad fosilífera del grupo Neuquén, Formación Río Colorado, al Sur de Mendoza, departamento Malargüe. $-X I$ Jornadas Argentinas de Paleontologia de Vertebrados, Tucumán, 17-20 de Mayo de 1995, res, p. 4.

ANdreis R.R., IÑiguez Rodriguez A.M, Lluch J.J. \& SABIo D.A. (1974). - Estudio sedimentológico de las formaciones del Cretácico superior del área del Lago Pellegrini (provincia de Río Negro, República Argentina).-Asoc. Geol. Arg. Rev. 29, 1, 85-102.

Bona P., Cladera G. \& Fuente M. de la (1998). - Las tortugas pleurodiras de la Formación Salamanca (Paleoceno inferior) en el área de Cerro Hansen, provincia de Chubut, Argentina. - Actas $X$ Congreso Latinoamericano de Geologia y VI Congreso Nacional de Geología Económica 1, 269-274, Buenos Aires, Noviembre de 1998.

Bour R. \& PAuler I. (1987). - Identité de Phrynops vanderhaegei Bour, 1973, et des espèces affines (Reptilia-Chelonii-Chelidae). - Mesogée, 47, 3-23.

Broln F. de (1987). - The Late Cretaceous fauna of Los Alamitos, Patagonia, Argentina. Part IV, Chelonia. - Rev. Mus. Arg. Ciencs. Nat. "Bernardino Rivadavia" Paleont., 3, 3, 131-139.

Broln F. de (1988).- Les tortues et le Gondwana. Examen des rapports entre le fractionnement du Gondwana et la dispersion géographique des tortues pleurodires à partir du Crétacé. -Stud. Geol. Salman., Stud. Palaeochel. 2, 5, 103-142.

Broin F. de \& Fuente M. de la (1993).- Les tortues fossiles d'Argentine : Synthèse. - Ann. Paléont., 79, 3, 169-232.
Boulenger C. (1889). - Catalogue of the Chelonians, Rhynchocephalians and Crocodiles in the British Museum (Natural History), Trust. Brit. Mus. (Nat. Hist.), London, $311 \mathrm{pp}$.

Fuente M.S. de la (1992). - Las tortugas Chelidae del Terciario superior y Cuaternario del territorio argentino. - Ameghiniana, 29, 3, 211-229.

GAFFNEY E. S. (1977). - The side-necked turtle family Chelidae : a theory of relationships using shared derived characters. - Amer: Mus. Nov., 2620, 1-28.

GAFFney E. S. (1979). - Fossil Chelid turtles of Australia 4 - Amer: Mus. Nov. 2681, $1-23$.

GAFFNEY E. S. (1981). - A review of the fossil turtles of Australia. - Amer: Mus. Nov, 2737,1-38.

GAFFneY E.S. (1991). - The fossil turtles of Australia. In: P. Vickers-Rich, J.M. Monaghan, R.F. Baird and T.H. Rich Eds, Vertebrate palaeontology of Australasia, 704-720.- Pioneer Design Studio, Lilydale, Victoria, 1437 p.

Gaffney E. S., Archer M. \& White A. (1989). - Chelid Turtles from the Miocene freshwater limestones of Riversleigh Station, Northwestern Australia. - Amer: Mus. Nov. 2959, 1-10.

Gasparini Z. \& Fuente M. de la (2000). - Tortugas y plesiosaurios de la Formación La Colonia (Cretácico superior) de Patagonia, Argentina. - Rev. Esp. Paleont. 15, 1, 23-35.

Guibe J. (1970).- Le squelette céphalique. In : P.-P. GrassÉ, Traité de Zoologie, T. XIV, Reptiles, c, caractères généraux et anatomie, fasc. 2, - Masson, Paris, 78-143. 
Heredia S. \& SAlgado L. (1999). - Posición estratigráfica de los estratos supra cretácicos portadores de dinosaurios en Lago Pellegrini, Patagonia septentrional, Argentina. - Ameghiniana, 36, 2, 229-234.

IVERSON J. B. (1992). - A revised checklist with distribution maps of the turtles of the world. - Privately Print., Richmond, Indiana, $363 \mathrm{p}$.

Lapparent de Broin F. de, Fuente M. de la \& Calvo J. (1997). - Presencia de los más antiguos quélidos (Tortugas pleurodiras) en el Cretácico Inferior de El Chocón, provincia del Neuquén, Argentina. - XIII Jornadas Argentinas de Paleontologia de Vertebrados (La Rioja). - Ameghiniana, 34, 4, 538.

Lapparent de Broin F. de \& Fuente M. de la (1999). - Particularidades de la fauna continental de tortugas del Cretácico de Argentina. XIV Jornadas Argentinas de Paleontología de Vertebrados (Neuquén, 1998). - Ameghiniana, 36, 1, 104.

Lapparent de Broin F. de \& Molnar R. (2001). - Eocene chelid turtles from Redbank Plains, southeastern Queensland, Australia.Geodiversitas 123, 1, (in press).

Leanza H. A. \& Hugo C.A. (1995). - Revisión estratigráfica del Cretácico inferior continental en el ámbito sudoriental de la Cuenca Neuquina. - Rev. Asoc. Geol. Arg. 50, 1-4, 30-32.
LEANZA H. A. \& Hugo C.A. (1999). - Información geológico minera de la provincia de Río Negro. In : Geología y Recursos Minerales de la Hoja 3966-III, Villa Regina. Río Negro, Proyecto Minero, Viedma, 1-30.

MANERA de BiAnCo T. (1996). - Nueva localidad con nidos y huevos de dinosaurios (Titanosauridae) del Cretácico superior, Cerro Blanco, Yaminué, Río Negro, Argentina. - Asoc. Paleontol. Arg., Publ. Spec. 4. - I reunión Argentina de Icnologia, 59-67.

Pritchard P. C. H. (1985). - Evolution and Zoogeography of south American turtles. - Stud. Geol. Salm,. Stud. Palaeochel., 1, 225-233.

Pritchard P. C. H. \& Trebbau P. (1984). - The turtles of Venezuela. Contributions to Herpetology, Soc. Study Amphibians, Reptiles Pub. Athens, Ohio, USA, 2, 403 p.

ROMER A.S. (1956). - Osteology of the Reptiles. - University of Chicago press, $772 \mathrm{p}$.

Staesche K. (1921). - Schildkrötenreste aus der oberen Kreide Patagoniens. - Palaeontographica, 72 (1-6), 103-123.

Wichmann R. (1927). - Facies lacustres senonianas de los estratos con dinosaurios. - Bol. Acad. Nac. Cien. 30, 383-406. 